\title{
Virus e monstros: \\ a representação da doença na série Alien
}

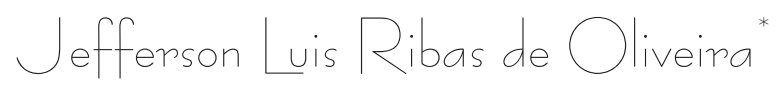

1. Introdução

Considerada uma das mais aclamadas e conceituadas séries de ficção científica, Alien se tornou uma obra referência para o cinema hollywoodiano, o que gerou e gera até hoje inúmeros filmes que tem nesta saga a base para sua inspiração. Um dos principais méritos da série é sua qualidade visual, o que permitiu que as produções não se tornassem "datadas"; ou seja, um espectador contemporâneo pode vê-las e sentir a mesma concepção e impacto que seus criadores almejavam originalmente, o que no cinema de ficção científica é muito importante.

Outro fator de grande importância é que seus quatro filmes foram realizados por diretores diferentes, o que de certa forma revela mudanças sutis nas abordagens dos personagens e de seus sentidos, como veremos. Os episódios de 1979, 1986, 1992 e 1997 se complementam, mas também se diferenciam em alguns aspectos. Um deles diz respeito aos significados que o monstro alienígena possui nas películas e às formas de interpretá-lo, o que demonstra o quanto os filmes de cinema, e os de ficção científica particularmente, são obras abertas, para as quais podemos lançar diferentes olhares sem esgotarmos a obra de arte em si.

* Mestre em História pela Universidade Estadual do Oeste do Paraná (Unioeste). Pesquisador das áreas de Cinema e História. E-mail: jeffersonribas31@yahoo. com.br 
Em um artigo em que analisa a série Alien, a historiadora Ana Paula Vosne Martins busca compreender os simbolismos ancestrais que a franquia de ficção científica atualiza. O medo da mulher, o mistério da maternidade, a caracterização dos monstros e da morte, a desnaturalização do ser humano e o domínio tecnológico são alguns dos temas que podem ser encontrados nos filmes da saga. ${ }^{1}$

Martins se pergunta se um filme hollywoodiano sobre monstros alienígenas pode trazer algum questionamento para o historiador. Sua resposta é positiva, já que entende que todo filme é histórico e realizado num período especifico, portanto, pode ser usado sim como fonte de pesquisa. Um aspecto considerado revolucionáriopela autora na série Alien é o fato de uma mulher aparecer como protagonista, quebrando o sentido patriarcal e machista que os filmes deste gênero sempre possuíram. A tenente Ripley:

[...] é fria ao tomar decisões, sabe manejar armas, lutar e pilotar naves espaciais. Na sua interpretação do sucesso dos filmes ela [Sigourney Weaver] ressalta que os filmes, contam, na verdade a história de uma heroina e que o fato de o papel ser interpretado por uma mulher foi revolucionário, pois afinal tratava-se de algo novo. ${ }^{2}$

Além das questões referentes à ficção científica enquanto gênero, formulações a respeito do corpo e da doença também podem ser visualizadas nos filmes da série, em alguns momentos de forma clara, em outros apenas veladamente. Tentarei pensar de que forma essas questões podem ser vistas nas películas apropriando-me das ideias de Francis Vanoye e Anne Goliot-Lété, para os quais analisar um filme é desconstrui-lo para depois reconstrui-lo. Ou seja, primeiramente a obra filmica deve ser decomposta, esmiuçada, despedaçada, tirada de sua totalidade, paraem seguida ser restabelecida, recriada pelo analista. É como se o filme "se movesse", superasse seus significados originais para que

${ }^{1}$ MARTINS, Ana Paula Vosne. Laços de Sangue: representações do feminino e da maternidade no cinema de ficção científica. In: ArtCultura. Uberlândia, Edufu, jul/dez de 2003/ jan/jun de 2004, vol. 5, n 7, / vol. 6, nº 8, p. 64-73.

2 Ibidem, p.67-68.

272 Revista de História Regional 16(1): 271-295, Verão, 2011 
outros viessem à tona. É um processo em que a linguagem cinematográfica se mostra complexa, porém muito mais rica para o desenvolvimento de sua análise.

\section{A saga de Ripley}

O primeiro filme da saga, Alien, o oitavo passageiro (Alien, 1979), foi dirigido pelo inglês Ridley Scott. No início, vê-se a nave Nostromo cruzando alguma galáxia. Em seu interior, soturno e sem brilho, sete tripulantes são acordados de um longo sono pelo computador denominado Mãe. Pouco tempo depois, esses constatam que a rota original da nave foi modificada pelo computador, o que os faz pousar em um planeta inóspito, o LV-426. Ao chegar ao planeta, a nave se danifica e os dois mecânicos concluem que levará horas para ser consertada. Três tripulantes, Kane, Dallas e Lambert resolvem sair da nave e ir para o lugar indicado por Mãe. Descobrem outra espaçonave abandonada em meio a grandes rochedos e um tipo de vida que ali sobrevivera, mas que se encontra fossilizada. Kane descobre uma caverna, encontrando ali inúmeros casulos no chão, todos protegidos por uma tênue neblina. Ao perceber um movimento em um dos casulos, Kane se aproxima. O casulo se abre e, quando ele chega mais perto, algo o ataca.

Dallas e Lambert retornam à nave com Kane ferido. A tenente Helen Ripley (interpretada pela atriz Sigourney Reaver) decide proibir a entrada deles, por não saber o que atacou Kane. O cientista da nave, Ash, desrespeitando ordens, abre a escotilha para os três tripulantes entrarem. Kane é levado à enfermaria e ali o grupo descobre uma estranha forma de vida presa ao seu rosto. Ash e Dallas tentam fazer uma operação para retirar a criatura, mas, ao ter uma de suas veias cortadas, o organismo expele ácido, que derrete o chão da enfermaria e também do andar de baixo da espaçonave. Assustados, os demais não sabem o que fazer.

Tempos depois, voltam a visitar a enfermaria e o organismo não se encontra mais no rosto de Kane. Apenas 
encontram caídos ao chão o que parecem ser pedaços da pele do ser alienígena. Em seguida, Kane se recupera, o que surpreende a todos. Durante uma refeição, no entanto, volta a passar mal e, na cena mais famosa do filme, um monstro sai de seu estômago. É uma criatura pequena, com uma estrutura estranha. Sua cabeça é redonda e seu corpo gelatinoso. Seus dentes são afiados e seus olhos quase não se abrem. Coberto pelo sangue de Kane, ele corre pela mesa de refeições e foge da sala. Os seis sobreviventes então se dividem para matar aquilo que não conseguem definir. Pouco depois, descobrem que o organismo se tornou maior do que um ser humano. Se o ser que saiu do estômago de Kane tinha uma cor amarelada, agora ele é todo escuro, com uma face monstruosa alargada para frente. Uma espécie de liquido pegajoso sai de sua boca e, ao abri-la, um pequeno ser disforme alojado em sua garganta se mostra.

Brett e Dallas são os próximos a serem assassinados pela criatura. Em seguida, o cientista Ash é morto pelos próprios sobreviventes, quando esses descobrem que ele é na verdade um robô enviado pela Companhia, empresa proprietária da Nostromo. Parker e Lamberttambém são executados pelo alienígena, sobrando apenas Ripley. Ela escapa da Nostromoem uma pequena cápsula espacial, explodindo a nave-mãe na esperança dematar o ser invasor. Mas, ao final, ele reaparece tão letal quanto antes. Ripley, que nesta última sequência está usando apenas roupas de baixo, expulsa o alienígena para o vácuo, terminando como sobreviventes apenas ela e o único animal da nave, o gato Jonesy. No fim, ela deixa a mensagem: "aqui é Ripley. Única sobrevivente do Nostromo".

O segundo filme da série, Aliens, o resgate (Aliens, 1986), foi realizado sete anos depois e contou com a direção de James Cameron. Qual seria o enredo dessa sequência?No espaço sideral, uma pequena espaçonave é encontrada. Uma máquina penetra a nave e usa uma espécie de raio laser para tentar encontrar algum tipo de vida em seu interior. Surpreendentemente, dois seres vivos são encontrados: um pequeno gato e uma mulher. Trata-se de Helen Ripley. Ela

274 Revista de História Regional 16(1): 271-295, Verão, 2011 
acorda em uma enfermaria e nota que está medicada. Descobre então, por meio de um membro da Companhia para a qual trabalhava, que ficou no espaço por 57 anos, vagando pelo vácuo em sua nave. Como resultado, Ripley fica totalmente horrorizada com o ocorrido. Após pegar no sono, sente algo estranho dentro de seu corpo. Começa a sofrer dores terriveis e então o monstro alienígena emerge de seu estômago, da mesma forma como acontecera com Kane no filme anterior. Mas ela acorda e descobre ser apenas um sonho. Percebe que está sã e salva na enfermaria, porém estranha tudo naquele lugar.

Na manhã seguinte, Ripley pergunta sobre sua filha. $\mathrm{O}$ agente da Companhia comenta que ela, infelizmente, havia morrido dois anos atrás, com 66 anos. Ripley fica ainda mais desolada ao ver uma fotografia de sua filha já idosa e se sente mal por não poder ter vivido ao seu lado.

Ripley é levada a julgamento por ter destruído a Nostromo. Peritos leemos arquivos da nave, nos quais Ripley comenta que ela havia sido invadida por um ser que é "gestado dentro de um corpo humano" e que "tem ácido no lugar de sangue". Os especialistas não acreditam no relatório de Ripley, que é considerada "louca" e obrigada a passar seis meses em tratamento médico. No decorrer da trama, descobre que LV-426, o planeta onde o monstro foi encontrado no primeiro filme da saga, foi colonizado há tempos.

Em LV-426, num clima tempestuoso e infernal, uma família, composta por um casal jovem e seus dois filhos pequenos, percorrem um ambiente extremamente hostil numa espécie de tanque high-tech. O pai recebe um sinal de repente e, junto com a mulher, se dirige ao local de onde vem o chamado para verificaremdo que se trata. Após algum tempo, a mulher reaparece horrorizada e pedindo ajuda, enquanto do lado de fora podemos ver que o homem tem um monstro ocupando totalmente sua face.

Através de um agente da Companhia, Ripley recebe a notícia de que as comunicações com o planeta LV-426 haviam sido cortadas. Ela então é persuadida a ir àquele planeta como consultora em uma expedição militar. Como recompensa, 
teria sua ficha novamente aceita pela Companhia, com o que acaba concordando. O grupo é todo formado por militares orgulhosos de seu conhecimento técnico e de sua experiência em combate. Ao chegarem a LV-426 não encontram ninguém, apenas destruição. Penetrando o complexo de colonização, encontram uma estranha forma de vida, que suga os corpos das pessoas e os prende em suas próprias estruturas fisicas, grudadas nas paredes.

Inicia-se novamente o pesadelo do primeiro filme, em que o alienígena, agora não mais sozinho, mas às centenas, ataca os humanos. Em meio a essa guerra há um espaço de sensibilidade entre Ripley e a menina Newt, única sobrevivente daquela família e de todo aquele planeta.

Ao final, depois de Newt ser presa pela fêmea alienígena que coloca ovos, Ripley consegue primeiro matar os futuros filhotes e destruir a instalação militar, travando em seguida uma batalha com o organismo extraterrestre - que neste filme é mostrado como do gênero feminino, e não como a entidade masculina do primeiro episódio. Com a ajuda de uma empilhadeira, Ripley derrota o monstro, expulsando-o para o espaço. Ao final sobrevivem Ripley, a menina Newt, o andróide Bishop e o cabo Hicks, um dos militares da Companhia.

O terceiro filme da saga, Alien $^{3}$ (1992), foi o trabalho de estreiado diretor David Fincher. ${ }^{3}$ Das quatro produções, essa foi a que mais gerou problemas ao estúdio 20th Century Fox, que realizou toda a série. Durante anos, o filme foi criticado por não estar à alturados dois episódios anteriores, graças a um roteiro truncado e um final desanimador. Ainda que grande parte das ideias do roteiro original tivessem sido mantidas, o estúdio sugeriu mudanças e cortes, o que gerou protestos dos atores e do próprio diretor. ${ }^{4}$ Além disso, a obra

\footnotetext{
${ }^{3}$ David Fincher é norte-americano é iniciou sua carreira artística dirigindo videoclipes. Entre suas produções mais destacadas, destaque para Seven - Os Sete Crimes Capitais (Seven, 1995) e A Rede Social (The Social Network, 2010).

${ }^{4}$ Há duas versões desse filme. A versão "oficial" foi a que passou nas salas de cinema no ano de 1992. Em 2003 foi lançada em DVD a "versão do diretor", com trinta minutos a mais de duração, e algumas pequenas mudanças na narrativa. É a partir dessa segunda versão é que faço minha análise.
}

276 Revista de História Regional 16(1): 271-295, Verão, 2011 
possuía toda uma atmosfera dark, visual criado por Fincher e que decepcionou muitos velhos fãs da série. Mesmo com todos esses problemas em sua etapa de produção, a obra não deixou de ser apreciada no decorrer dos anos. Martins, no entanto,considera esse filme da série o mais rico de todos, por ser o mais repleto de simbolismos e mostrar de forma mais impactante o significado do feminino e da maternidade. ${ }^{5}$ Também acredito que este seja o episódio mais rico da franquia, mas vejo nele outros significados para serem trabalhados; significados esses que o monstro adquire durante a trama, que delineia de forma mais sombria o sentido velado de doença que a monstruosidade assume, conforme veremos mais à frente.

Uma nave espacial cai em um planeta desconhecido, cujo nome é Fury 161. Há ali uma colônia penal habitada por 25 homens, presos por crimes hediondos e que formam dentro da prisão uma seita fundamentalista cristã. Dando continuidade aos outros filmes da série, a única sobrevivente é a tenente Ripley. Ela é encontrada e tratada pelo único médico da colônia, Clemens. Ao emergir de seu estado inconsciente, descobre que os outros tripulantes de sua nave morreram e pede ao médico que faça uma autópsia nos corpos, afirmando que eles podem trazer algum tipo de virus. A autópsia é realizada, mas nada é encontrado. Ripley pede então que os corpos sejam incinerados e é prontamente atendida.

Na oração da unção dos enfermos, celebrada pelo líder espiritual da seita, Dillon, o monstro alienígena aparece pela primeira vez no filme e logo faz sua primeira vítima. Ripley vai até o refeitório do presídio e nota que não é bem vinda ali por ser mulher. A única pessoa que a trata bem é Clemens e em pouco tempo os dois iniciam um romance. $\mathrm{O}$ invasor alienígena inicia sua caça aos prisioneiros. Um por um eles vão sendo assassinados. Os poucos sobreviventes resolvem se organizar para derrotar a criatura. Nesse meio tempo, Ripley sente-se cada vez pior de saúde. Faz um exame e descobre que está grávida do monstro alienígena. Pede que Dillon

${ }^{5}$ MARTINS, op. cit., p. 70. 
a mate, mas ele nãoaceita fazê-lo. A Companhia, para qual Ripley trabalha, descobre sua gravidez e manda uma equipe médica para o planeta. Ela entra em desespero, temendo que a Companhia mantenha o monstro vivo para poder estudá-lo.

Os prisioneiros, sob o comando de Ripley, resolvem montar uma última armadilha para derrotar o alienígena. A tentativa, no entanto, acaba sendo em vão e quase todos morrem, restando ao final Ripley e um único prisioneiro. A equipe médica enviada ao planeta a encontra, mas Ripley foge. Depois de encurralar o monstro numa fundição, mata-o. Perseguida novamente, agora pelos médicos, a protagonista decide tomar uma atitude drástica. Comete suicídio, atirando-se no forno de aço derretido da prisão, tirando a própria vida e a do monstro que carrega dentro de si.

Após cinco anos, a série ganhou sua derradeira parte - Alien: a ressurreição (Alien: Resurrection,1997), realizada pelo francês Jean-Pierre Jeunet. A trama se inicia na espaçonave SnuAuriva, uma nave de pesquisa médica, na qual a tenente Helen Ripley desperta de um sono prolongado. Ela se vê em uma enfermaria, em meio a um grande número de médicos e cientistas. Após conversar com um deles, descobre que foi clonada e que seu filho inumano da trama anterior encontra-se guardado em um tubo de vidro ultraprotegido para que a espécie seja estudada. Em sua primeira aparição, o monstro alienígena é um ser estranho, de forma indefinida, que mais se assemelha a um bebê deformado.

Neste instante, um grupo de contrabandistas chega à instalação trazendo prisioneiros. Saberemos depois que são, na verdade, cobaias para as experiências científicas, ou seja, que se trata de algo criminoso, mas realizado livremente. Como nos três filmes anteriores, a Companhia deseja controlar a espécie alienígena e torná-la arma militar. Ripley, que nesta sequênciafoi clonada juntamente com seu "filho" alienígena, acaba recebendo DNA da aberração. Da mesma forma, o organismo alienígena recebeu material genético humano, o que os torna, de certa maneira, ligados biologicamente.

Os contrabandistas tentam entrar nas instalações científicas, mas são impedidos, pois ali "são proibidas do- 
enças infecciosas" e o "acesso ao laboratório é negado a civis". Como nas histórias anteriores, o inesperado acontece e o organismo alienígena inicia sua caçada de sangue. Perseguidos, Ripley e o grupo externo se unem para enfrentá-lo, já que todos os cientistas e militares da Companhia são executados.

Ripley chega a um laboratório onde experiências estavam sendo realizadas. Os seres mantidos dentro das incubadoras de vidro são tenebrosos, revelando uma mistura de humanidade e monstruosidade, o que os torna visualmente ainda mais terriveis. Com um lança-chamas, ela elimina todos aqueles seres. Após passarem por um subterrâneo aquático, onde nem todos conseguem sobreviver ao ataque devastador do alienígena, os sobreviventes se retiram da instalação, que explode no espaço, tomando uma nave com destino à Terra.

No entanto, o monstro também consegue entrar na nave, levando à frenética batalha final. Ripley e o monstro se encontram, o que dá a cena certo estranhamento, já que ambos, apesar de serem eternamente inimigos, estão unidos por laços biológicos. De uma forma sombria, estão juntos numa relação genética. Matar um é como destruir também o outro.

Mesmo assim, o instinto de sobrevivência como espécie humana de Ripley é mais forte e ela mata pela última vez a criatura, expulsando-a da nave. O alienígena é então sugado pelo vácuo e a protagonista se liberta em definitivo de seu maior adversário. Por fim, a espaçonave chega a Terra, que é mostrada pela primeira vez em toda a saga. A frase de Helen Ripley na cena final é significativa: "Também sou uma estranha aqui."

\section{A representação da doença na série Alien}

Na série Alien, podemos encontrar alguns temas que são constantes em todas as produções. Em primeiro lugar, 
podemos destacar o confronto entre humanidade e monstruosidade. Além disso, a ciência militar é sempre vista como um grande inimigo, já que em todos os filmes a Companhia quer se apoderar do organismo para usá-lo como uma arma biológica. Outro ponto comum a ser apontado é a questão do gênero, já que a figura da protagonista em nenhum momento demonstra fragilidade, mas sim força e inteligência para sobreviver. Os filmes apresentam uma visão futurista de um mundo dominado por uma ideologia sombria, uma vez que a Companhia, uma empresa de mineração e colonização, tudo domina e assume o papel e o poder de Estado, uma vez que é ela quem cria as leis, as executa e julga seus adversários, eliminando-os. Em relação ao quarto filme, a questão da clonagem, bastante contemporânea à época (1997) devido à ovelha Dolly, também é tratada. A clonagem aparece na obra como algo ainda totalmente "antinatural", como quase tudo na série que se relaciona a algo que escapa ao domínio do conhecimento humano. Muito do que existe de mais assombroso nas histórias de ficção científica tem origem exatamente nessa tentativa de controle das leis da natureza, imaginada como uma entidade que, senão é vista como algo além da compreensão, ao menos parece estar muito fora de nossa autoridade: não sabemos bem no que dará a inversão de suas leis. Além disso, a questão da doença, que nos interessa sobremaneira nesta análise, é tema recorrente e relevante em toda a série.

Uma sequência representativa em Alien: a ressureição se dá exatamente quando a protagonista e o grupo de contrabandistas encontram seres disformes em grandes tubos de vidro dentro de um laboratório. Troncos encurvados, dentes pontiagudos, olhos fora do lugar. A junção de corpos humanos com alguma coisa desconhecida gera algo monstruoso, inominável. É como se as fronteiras mais íntimas fossem derrubadas, dando origem a algo que não podemos aceitar, apenas destruir, como faz então Ripley. Essa cena no derradeiro filme dá o tom do conflito principal que se estabelece em toda a saga. Não apenas entre a tenente Helen Ripley e o ser alienígena, mas, principalmente, entre o que é humana- 
mente concebivel e conhecido e seu oposto, o desconhecido, o nãohumano.

É uma relação de conflito que se estabelece a partir daí, ainda que em algumas situações possa existir o diálogo ao invés do confronto. Mas, na série Alien, o que prevalece é a relação entre "nós", seres humanos, e "aquilo", aquela "outra coisa", entendido como o outro, o solitário, inóspito, o sombrio, por fim, o nãohumano.

No entanto, que tipo de coisa essa nãohumanidade poderia representar? Se essa fuga da compreensão humana busca encontrar o desconhecido, busca o fantástico, o encontro com algo que é considerado o "mal",é naideia de doença que ela encontra sua nomeação.

A representação do conceito de doença foi uma constante ao longo da História, em sociedades e espaços distintos. A doença e seus portadores sempre foram vistos como invasores, estrangeiros, poluidores dos corpos e também das almas. O mal físico sempre necessitou de uma "nomeação", algo que fosse entendido simbolicamente como algo além de uma irrupção corporal e/ou mental. Nesse sentido, como as representações de enfermidade e do corpo são visualizados nos filmes desta saga de ficção científica?

Uma das primeiras coisas que podemos notar em todos os filmes da série é que a história, no fundo, se mostra uma grande luta pela sobrevivência, colocando em polosopostos a humanidade e seu outro, o desconhecido e avassalador. Os filmes também não fogem do maniqueísmo. É o "bem" contra o "mal". Não há zonas cinzentas entre essas duas instâncias. Além disso, também é uma luta contra o que os próprios homens criaram, no caso, a tecnologia, uma tônica nas quatro produções, mas de forma mais evidente em Alien, o oitavo passageiro, de Ridley Scott. Como escreve o historiador Marcos Silva, esta "capacidade desdobrada numa avaliação dos labirintos a que a técnica humana conduziu seu inventor" é presença marcante na obra do diretor. ${ }^{6}$

${ }^{6}$ SILVA, Marcos. Ser o Talvez Semelhante: Os Pés Feridos de Deckard. In: SILVA, Marcos e CHAVES, Bené. Clarões da Tela. O Cinema Dentro de Nós. Natal: Editora da UFRN, 2006, p. 298. 
E a doença, de que forma se apresenta nesse imaginário científico dos filmes? Umaforma de enxergarmos isso é observarmos como o monstro alienígena se apresenta nas tramas. A primeira visão que temos dele em Alien, o oitavo passageiro é quando Kane se aproxima dos casulos enfileirados dentro da velha espaçonave encontrada em LV-426. A entidade biológica não nos é mostrada de forma clara, sendo apenas sugerida - o que contribui para a aura de mistério e terror que o personagem manterá por toda a série. Kane, ao descer naquele planeta inóspito, percebe que existe vida ali, mesmo em condições praticamente impossiveis para que algo pudesse se desenvolver. Porém, ele é atacado e o pesadelo ali se inicia. Se o sentido de exotismo e mistério cobre o personagem até então, seus significados vão, pouco a pouco, nos sendo revelados.

Dallas e Lambert encontram Kane e o levam para Nostromo. Ripley, que neste momento está no comando da nave, se recusa a abrir a porta para eles. Motivo: Ripley teme que Kane possa contaminar todos os outros. "É perigoso. Todos nós vamos morrer", é o que diz.

Ripley, ao afirmar que "aquilo" contaminará e matará a todos, já define o estranho como o "mal". Mas não qualquer definição de mal. Aquela entidade biológica pode muito bem ser interpretada como doença. Afinal, é a doença que contamina e que mata; é ela que se espalha e destrói o interior humano. É a doença que destrói a harmonia corpo/mente dos seres. Na sequência, Kane é levado para a enfermaria. Pela primeira vez temos uma visão mais explícita do monstro alienígena. Como uma massa pegajosa, o organismo se estende por todo o rosto de Kane. Suas veias circulam seu pescoço, quase o sufocando. Ao tentar examinar aquela massa estranha, Ash observa que os tentáculos podem matá-lo. Descobrimos que o organismo passa oxigênio para sua vítima e que, como um parasita, agora necessita daquele ser humano para poder viver.

Susan Sontag descreve o quanto o rosto é importante para as nossas percepções de saúde e de doença, assim como do que é belo ou repulsivo. Doenças estigmatizantes do

282 Revista de História Regional 16(1): 271-295, Verão, 2011 
passado, como a hanseníase e a varíola, devem muito do seu pavor ao fato de deixarem marcas na face de seus atingidos. A separação mente/corpo nas artes também teve ampla difusão nas pinturas de santos nas idades Média e Moderna. Nessas representações iconográficas, os "escolhidos" sofriam o martírio cristão, mas somente em seus corpos. Em suas faces, a beleza da cristandade permanecia, com expressões faciais que nada mostravam das terriveis dores corporais pelas quais passavam.

O próprio conceito de pessoa, de dignidade, depende da separação entre rosto e corpo, da possibilidade de que o rosto seja isento - ou ele próprio se isente - do que está acontecendo com o corpo. E, por mais letais que sejam, as doenças que, como as do coração e a gripe, não danificam nem deformam o rosto jamais provocam o terror mais profundo. ${ }^{7}$

A cena impactante de Kane com o rosto coberto pelo organismo alienígena traz à tona imagens de medo, nojo e repulsão. Trata-se da desfiguração do ser humano e da inclusão de uma nova identidade, que se situa entre o animalesco e o desconhecido.

Isso fica mais evidente na sequênciaseguinte, em que, ao ser cortada uma das veias do alienígena, ela expele ácido, derretendo o chão da enfermaria e também o do andar de baixo. O comandante Dallas usa uma caneta de Brett para mexer no líquido, devolvendo-a em seguida para ele. Essa curta sequênciatambém evoca imagens tradicionais sobre doença. A substância expelida, por ser de natureza estranha, traz consigo ideias de impureza. Impureza esta que deve ser combatida, afinal, ela pode contaminar tudo o que toca - principalmente os homens. Se considerarmos que, na verdade, o ácido que saiu daquele organismo é o seu sangue, a cena ganha toda uma representação simbólica. O sangue é o líquido vital para o corpo humano, afinal, ele é peça integrante de todo a complexa engrenagem da evolução humana. Juntamente com o sêmen, é o veículo essencial da

\footnotetext{
${ }^{7}$ SONTAG, Susan. Aids e Suas Metáforas. São Paulo: Companhia das Letras, 2007. p. 109.
} 
continuidade biológica. Por isso a ideia de contaminação e de impureza é tão fortemente associada à ideia de doença. É uma morte que se espalha, que precisa ser combatida, pois é dentro do corpo humano que se estabelece esse conflito. Essa é uma imagem que fica evidente na cena mais clássica de Alien, o oitavo passageiro: aquela em que o parasita rompe a pele e sai pelo estômago de Kane. Com um visual chocante, já que o monstro aparece em primeiro plano e em todos os seus detalhes, a cena se presta a múltiplas leituras.

Uma delas é a própria subversão da ideia de maternidade, conforme comenta Martins. No momento em que se inicia a caçada pelo monstro, Ash diz que aquilo que perseguem é o "filho de Kane", ou seja, um ser que nasceu de dentro de um homem, e não de uma mulher. Isso subverte totalmente a ideia de "natureza humana", tornando-se simbolicamente algo demoníaco, "nãonatural". 8

Mas a ideia de doença também pode ser compreendida, ainda que de forma velada. Afinal, como afirmamos acima, o corpo alienígena é entendido como um parasita, que ocupou o corpo de um homem para depois destruí-lo e se espalhar pelo ambiente. Na narrativa, a forma como o alienígena age se assemelha à de um vírus biológico.

Esta concepção de uma entidade biológica violenta e resistente a tudo, contra a qual o conhecimento humano não tem como agir, fica clara numa frase de Ash, que define a espécie alienígena como uma mescla de vírus assassino e inocência humana: "Um organismo perfeito. A perfeição de sua estrutura só é igualada por sua hostilidade. Admiro a sua pureza. É um sobrevivente despido de consciência, remorso ou ilusões de moralidade."

Se a luta pela sobrevivência em Alien,o oitavo passageirotoma ares aterrorizantes, isso se dá devido à concepção do mal que o monstro alienígena porta como representação. Uma entidade viva de origem desconhecida, que se mescla à pele humana para depois penetrar no corpo. Uma vez dentro dele, cria pouco a pouco uma nova estrutura parasítica,

${ }^{8}$ MARTINS, op. cit., p. 70.

284 Revista de História Regional 16(1): 271-295, Verão, 2011 
até destruir seu hospedeiro por inteiro e tentar, a partir daí, ocupar novos corpos e sobreviver biologicamente. O monstro alien, analisado mais atentamente, revela medos subliminares da doença e de suas formas de contágio, bem como o próprio imaginário que constrói a enfermidade como uma ideia.

Esses significados imputados à monstruosidade são retomados de forma mais profunda em Alien 3. A representação da monstruosidade alienígena em muito se assemelha a um tumor, a uma doença. Aquilo que tem dentro de si vai consumi-la, destruí-la, aniquilar seu corpo, e por fim, matá-la. Ele é um invasor silencioso que, quando menos se espera, ataca, polui, consome.

Ripley, em certo sentido, fica grávida. Mas trata-se de uma gravidez nãonatural. Não vai trazer a vida ao mundo, mas sim a morte. Dessa forma, o tom de doença da aberração adquire formas mais claras. "Equipe médica a caminho. Prioridade máxima. Tenente Ripley em quarentena”, ela vê, atônita, o aviso pelo computador da prisão. Perseguida e isolada, percebe o quanto de estigma traz em si.

"Se este organismo sair do planeta, arrasará com tudo"; "o que está dentro de mim pode gerar milhares." Ditas no calor do desespero, essas frases dão o tom simbólico da representação da doença como algo maléfico e mortal.

Neste terceiro filme da série Alien, podemos ver a representação mais fortemente significada através do monstro nãohumano. Uma entidade estranha ao corpo, de origem desconhecida, que o invade. É algo que polui o corpo, traz opacidade ao interior humano, que se torna um feixe para representações e nomeações do mal. Embora vivido na forma de pesadelo exterior - o terror vivenciado por todos os prisioneiros, um significado de "peste" que se espalha e mata a todos -, é no universo intimo, individual, que isso é mais fortemente visualizado.

É a tenente Helen Ripley que carrega o organismo dentro de si. Que há de sofrer todas as terriveis consequências disso. Porta uma entidade biológica e estranha que vai trazer destruição ao mundo. Nesse sentido, a cena comentada anteriormente lembra muito uma passagem do 
livro de Susan Sontag,quando a autora comenta sobre o câncer: "Mas esse caroço está vivo, um feto com vontade própria. [...] - 'eles crescem, são engendrados, engendram, tem uma estrutura, segregam, comem'. O câncer é uma gravidez demoníaca". 9

Ao final do filme, o suicídio de Ripley traz elementos do martírio cristão, mais particularmente de Joana d'Arce do próprio Cristo. Com os braços abertos e com a cabeça raspada, Ripley realiza um sacrificio pessoal. Tira sua vida para que todos os outros sejam salvos. O que podemos pensar a partir disso é que o indivíduo, o "doente", se sacrifica em favor da coletividade. Algo extremamente pessimista, afinal, a representação que se tem nesta película é que o próprio indivíduo se autoexclui, se autocensura - e, no limite, se autodestrói. Podemos argumentar que essa representação de doença na obra cinematográfica em questão culpabiliza, ainda que de forma velada, o próprio doente, além de não abrir nenhuma outra possibilidade além da autossegregação e da morte.

Em Aliens,o resgate, a monstruosidade se apresenta como um inimigo externo, além-corpo, algo exterior, e não interior como em Alien, o oitavo passageiro e Alien 3. Mas ela, no entanto, é igualmente destrutiva, diabólica. O filme de James Cameron traz alguns detalhes no roteiro cuja única função é sensibilizar o espectador em meio à ação incessante do filme, tendo poucas ligações com a produção anterior. Um exemplo é a filha de Ripley. Como no primeiro filme não é citado em nenhum momento que ela tinha uma filha, nesta sequência esta ideia é inventada para dar sentido à entrada de Newt na trama. Ripley, neste caso, é a mãe ferida, sensibilizada pela perda de quem mais amava, que acaba tirando o significado de sua vida. Quando encontra Newt, porém, é como se reencontrasse com sua filha morta, quando seus sentidos e sentimentos maternos voltam a aflorar. Veladamente, o filme é um confronto permeado pela idéia de maternidade. Tanto Ripley quanto a "mãe" alienígena querem

\footnotetext{
${ }^{9}$ SONTAG, Susan. A Doença como Metáfora. São Paulo: Companhia das Letras, 2007. p. 19.
}

286 Revista de História Regional 16(1): 271-295, Verão, 2011 
possuir a menina, e esse conflito simbólico e violento está presente em toda a película. ${ }^{10}$

Se a ideia de doença perpassa todo o primeiro filme, na produção de James Cameron isso não é explícito, talvez pela postura mais comercial que este acabou tomando. $\mathrm{O}$ monstro alienígena é representado como "um tipo de parasita" e como um "embrião", todavia, essas questões são pouco aprofundadas na película. Nesse sentido, a monstruosidade alienígena não se mostra com um devastador interno do corpo humano, mas sim como um inimigo externo, um outro que é negação da vida como ela é entendida.

Apesar de o terceiro filme da saga se centrar no confronto entre humanidade refugiada e a monstruosidade explícita, ele possui elementos bastante reveladores em relação às outras produções. Ao longo de todaa película, o monstro alien parece carregar, de forma metafórica,a alegoria da doença como elemento subliminar. Contudo, não é apenas ele. Outras características no roteiro dão o tom da enfermidade como metáfora para a construção filmica, o que confere a terceira parte de Alien sentidos singulares.

No filme, Fury 161, o planeta-mosteiro, traz juntamente com seus sombrios personagens duas instituições que no enredo se mesclam: a prisão e o sanatório. A sindrome do "duplo Y", conforme escrito no letreiro inicial, dá àqueles personagens uma dupla anormalidade, uma biológica e outra social.

No universo mítico da obra, eles foram banidos da sociedade, do universo inteiro, ganhando um planeta só para vivenciarem isoladamente suas angústias. Mas eles cometeram assassinatos, roubos e estupros por já possuírem esse "duplo Y", ou estão isolados devido exatamente a uma vida criminosa e de excessos? Quer dizer, a síndrome de que padecem é biológica ou social? Essa é uma questão que o filme não responde, mas possui grande representatividade. Seja qual for o caso, eles são "doentes sociais". A violência e a doença têm a mesma origem maléfica, e para isso são

${ }^{10}$ MARTINS, op. cit., p. 69-70. 
necessários os mesmos remédios: o isolamento total e absoluto.

Estes "doentes sociais", como aqueles que carregam o mal dentro de si, têm de ser controlados e excluídos, banidos do meio social. E o que possuem pode se espalhar, contaminar a todos, seja uma síndrome, seja a violência. Eles precisam ser segregados de todo o universo.

A religião também é um fator relevante em Alien 3 porém, é mostrada de forma negativa. No local existe uma forma de comunidade na qual parece não haver fé - afinal, foram esquecidos naquele lugar - e onde parece só haver espaçopara o terror, o medo e os dogmas ortodoxos. A chegada de Ripley, a mulher sobrevivente, entra em choque com os princípios daquele lugar, "a violação da harmonia e possivelmente da unidade espiritual", como diz Dillon, antes de vê-la. "Desaprovo a política da Companhia, que permite que uma mulher se misture com presos e funcionários", é o que diz um dos prisioneiros. Ripley representa ali um medo intolerável.

Essa misoginia representada em Alien 3 traz muita ideias tradicionais a respeito da discriminação da mulher, conforme analisado por Jean Delumeau. Esse estranhamento a respeito do "segundo sexo", os mistérios que envolvem o corpo feminino, sua sexualidade e o dom da maternidade, geraram nos homens de conhecimento durante séculos pensamentos machistas e atitudes violentas. A mulher como um ser poluído, que traz o pecado e a discórdia, foi recorrente na Idade Moderna. Ela era uma das servas de Satã. ${ }^{11}$

Mas e quanto ao gênero feminino, ele poderia ser entendido como doença? Pois essa é uma interpretação possivel na terceira parte da saga Alien. Desde que chega à prisão masculina, Ripley é tratada como a personificação do mal. Tem os seus cabelos raspados, é obrigada a usar um uniforme masculino, imundo e acinzentado como os dos outros prisioneiros. O que se vê é uma tentativa de negar 11 DELUMEAU, Jean. História do Medo no Ocidente. 1300-1800. São Paulo:
Companhia das Letras, 2004, p. 301-349.

288 Revista de História Regional 16(1): 271-295, Verão, 2011 
sua sexualidade. Isso, no entanto, não dá certo, pois ela se envolve sexualmente com Clemens, quebrando os códigos de conduta da prisão e da seita misógina. "Contato físico. É contra as regras, não é?", é o que diz.

Esse comentário de Ripley pode ser visto de uma forma mais densa. Além de ela e Clemens terem uma relação sexual, o que viola os tabus daquela seita cristã, o contato do corpo subentende outra ideia: a do contágio. A concepção de passar para outro indivíduo algo que tem dentro de si, nesse caso entendido como maléfico. Como um espaço íntimo, de fronteira, o corpo é definido como um antro de pecado e de devassidão. E pode ser visto de forma ainda mais perigosa. Seus fluidos ocasionam a contaminação, a poluição.

No entanto, não é apenas o corpo feminino que traz o mal àquele lugar. O que está dentro dele também assusta - e é a partir daí que podemos voltar aos sentidos que a monstruosidade alienígena adquire neste filme.

A chegada de Ripley aFury 161 traz dois tipos de medos àqueles homens. O primeiro é o feminino e, o segundo, a ideia de doença. Ao saber da morte da queda da nave dos outros tripulantes, ela pede para que seja feita uma autópsia na menina Newt. Segundo Ripley, a menina pode trazer algum tipo de contaminação. Clemens: "De que tipo?” Ripley: "Cólera." Clemens: "Não há um caso de cólera há 200 anos."

A autópsia é realizada no corpo franzino de Newt, mas nada é encontrado. "Não há sinal de contaminação ou doença... Não há sinal de doença contagiosa", diz o médico. Mesmo assim, Ripley pede para que os corpos de Bishop, Hicks e Newt sejam incinerados. Indagada sobre o porquê disso, responde: "É uma questão de saúde pública".A simples ideia de um vírus indesejável é intolerável. Uma epidemia de cólera não cairia muito bem no relatório", afirma o diretor da prisão, atendendo ao pedido da sobrevivente.

Clemens, como médico, sabe o que uma doença pode causar naquele lugar tão desprotegido. Assim, o imaginário do horror, já tão arcaico, é retomado em um universo futurístico em que não há tecnologia e tampouco outros meios para se proteger. Tanto externamente, já que se mostrará que não 
existem armas para enfrentar a monstruosidade alienígena como no segundo filme da franquia, quanto internamente, como no primeiro, pois os corpos dos prisioneiros não têm anticorpos, o que os deixa imunes a qualquer risco. Mas, no fundo, a aberração extraterrestre articula os dois perigos de uma forma alegórica.

Assumindo o controle dos prisioneiros para enfrentar o inimigo, já que ninguém possui treinamento militar, Ripley vai pouco a pouco se sentindo mal. Realiza um exame médico e descobre que tem um monstro dentro de si. Algo ainda pequeno, mas vivo, crescendo minuto a minuto, uma entidade mortal em suas entranhas. Sua morte parece se aproximar.

Essa relação mãe-filho é retomada miticamente na série pela sua relação "nãonatural". Em Alien: aressurreição, a mulher e monstro lutam pela sobrevivência usando de todas as formas as estratégias que a natureza deu a cada um deles. Os laços biológicos que os unem servem apenas para aprofundar ainda mais a estranheza entre o que é conhecido e o que é desconhecido. E,nesse sentido, o corpo deve ser entendido como uma fronteira, um espaço intimo que, se atacado, pode produzir os nossos mais inomináveis pesadelos. A última frase da protagonista no derradeiro filme, "Também sou uma estranha aqui", dá o tom de ter gerado algo estranho a si mesmo. Algo vivo, porém nãohumano; algo que já estabelece uma alteridade com relação aos outros de sua raça. Uma outra identidade.

\section{A Aids e suas imagens}

Mascomo podemos perceber estes medos que se encontram nesta série de ficção cientifica,tais como a enfermidade, a mulher e o indivíduo? Como relacionar estes documentos que recriam um mundo futurístico tão frio e cruel com a nossa realidade histórica. Se pensarmos que os filmes se realizam no recorte temporal 1979-1997, abrimos uma possibilidade de leitura da série - uma entre múltiplas possiveis, afinal, o documento cinematográfico é uma obra aberta. Mas 
como enriquecer nosso olhar ao revermos a franquia Alien?

Se uma doença pode ser considerada extremamente marcante no final do século XX, esta doença é a Aids. A Síndrome da Imunodeficiência Adquirida (ou SIDA) é uma enfermidade causada por um retrovírus que, ao se instalar no corpo humano, desestabiliza o sistema imunológico, deixando o organismo exposto a doenças oportunistas cuja evolução pode ser mais profunda. ${ }^{12}$

Quando os primeiro casos da doença vieram à tona (um grupo de cinco pessoas de Los Angeles, que tiveram algo que se assemelhava a uma infecção pulmonar entre outubro de 1980 e maio de 1981), não se poderia prever que em poucos meses esta "nova" enfermidade se tornaria uma pandemia. Digo "nova" porque, na verdade, não se sabe há quanto tempo o vírus está na natureza, podendo ser milenar. Os médicos e epidemiologistas, no entanto, são unânimes em afirmar que no século XX, devido ao maior contato entre pessoas de diferentes lugares e ao avanço dos meios de transporte e locomoção, um vírus que se contrai pelo contato físico ou através dos fluidos teve maior capacidade de espalhar pelas sociedades como um todo.

Desde o princípio da epidemia, a estigmatização e o preconceito tornaram-se características ligadas aos chamados soropositivos. Motivo: os cinco primeiros doentes diagnosticados eram homossexuais. Na verdade, quando a doença começou a intrigar os médicos e a ser noticiada pela imprensa, se criou todo um imaginário dentro do qual este mal "desconhecido" só atingiria os homossexuais. Todo esse preconceito criado pode ser analisado através das primeiras denominações que a Aids teve antes de ganhar seu nome (somente estipulado em 1982); entre eles, cabe destacar denominações como WrathofGodSyndrome (Síndrome da Ira de Deus), "pneumonia gay", "peste gay", "câncer gay", "sindrome gay" e Gay RelatedImmuneDeficience (GRID) - imunodefi-

12 NASCIMEnTO, Dilene Raimundo do. As Pestes do Século XX. Tuberculose e Aids no Brasil. Uma História Comparada. Rio de Janeiro: Editora da Fiocruz, 2005, p. 85. 
ciência ligada ao homossexualismo. ${ }^{13}$

Dilene Nascimento analisa o tom do imaginário produzido nos primeiros tempos da Aids:

Portanto, a Aids foi inicialmente identificada como uma sindrome que acometia indivíduos do sexo masculino e homossexuais. A identificação clínica da Aids ocorreu primeiramente nos EUA, onde logo, e quase exclusivamente, os homossexuais masculinos foram categorizados como grupo de risco. Não demorou, porém, e se constatou a ocorrência da doença em usuários de drogas injetáveis e hemofilicos, aumentando então o numero dos grupos de risco, mas sobre os quais se manteve a concepção de grupos exclusivamente atingidos pelo mal. A Aids permanecia, assim, como uma doença "estranha" que acometia pessoas consideradas "estranhas". ${ }^{14}$

Ao analisar as representações da lepra e da Aids através principalmente de documentos escritos, o historiador Ítalo Tronca, da Unicamp, observa três imagens citadas de forma recorrente. A Raça, o "perigo amarelo" e oriental, no caso da lepra, no século XIX; o negro africano ou haitiano no caso da Aids; a Geografia, o mal vem sempre de fora, do país estrangeiro, trazido pelo imigrante, envolto em exotismo e mistério (no caso, em ambas as enfermidades); e a Sexualidade: o doente de Lepra é mostrado em algumas representações como voluptuoso "por natureza", sedento por satisfazer seus desejos carnais.Já no caso da Aids, a sexualidade é ainda mais evidente, por se tratar de uma enfermidade também adquirida pelo contato sexual. Há nessas representações uma mesma "camada epistemológica", uma mesma ideia de negar a História, culpabilizando os próprios doentes e dando-lhes uma teia de significações, exposta em palavras como "pecado", "punição", "peste", "contágio", "culpa".

A Aids, principalmente na década de 1980, estigmatizou profundamente as pessoas incluidas nos chamados "grupos de risco". Ainda que no final dessa mesma década e

${ }^{13}$ NASCIMENTO, op, cit., p. 82.

${ }^{14}$ Ibidem, p. 83.

292 Revista de História Regional 16(1): 271-295, Verão, 2011 
nos anos 1990 a quantidade de afetadoscomo um todo tenha mudado o perfil dos chamados soropositivos, marcas daquela época ainda chegam até nós, travestidas agora de outras formas em novos grupos sociais.

Mas,afinal, onde entra a série Aliennessa história? Bem, neste artigo, buscou-se analisar como o monstro alienígena, que ao lado da tenente Helen Ripley é protagonista da saga, se apresenta muitas vezes como representação da doença. Não da Aids especificamente, mas da ideia de doença de forma mais geral. Algo biologicamente misterioso e desconhecido por penetrar o corpo humano e que pouco a pouco o aniquila. "Organismo perfeito", "parasita", "embrião", "doença contagiosa", "vírus indesejável” são algumas representações que este personagem não humano ganha ao longo da franquia.

O personagem alientraz a ideia do estrangeiro, do hospedeiro, do mal desconhecido, do que está além da imaginação e do conhecimento. E no caso do primeiro e do terceiro filmes, nos quais essa ideia se constrói de forma mais clara, é algo que está dentro do corpo humano. Por entre suas entranhas. No mais íntimo âmago do ser. Esta criatura maligna que divertiu e assustou plateiaspelos quatro cantos do mundo tem sua representação plenamente metaforizada. É algo extremamente simbólico.

Com relação à personagem Ripley, ela também tem uma grande significação, principalmente nas formas como vai aniquilando seu adversário, sem nunca exterminá-lo por completo. Se toda a série é uma representação, o mundo criado nestes filmes de ficção científica é o de um universo permeado pela técnica, pela tecnologia, em que as relações humanas são mediadas pelo dinheiro e pelo poder, pelo "avanço da ciência" independentemente do que precise ser destruído. Vistos em retrospectiva, os quatro filmes da franquia mostram o ser individual como o salvador absoluto. Ou salvadora, já que Ripley sobrevive a tudo. Se a coletividade se articula para vencer algo, ela logo se mostra um logro, uma insanidade. É assim tanto na espaçonave Nostromo, quanto na prisão-mosteiro de Fury 161. É ao indivíduo que é dado o poder de salvação, não ao coletivo. 


\section{Considerações Finais}

Contudo, se esta saga de terror futurista pode representar um elogio ao self-mademan, ao homem liberal, existe algo profundamente negativo que perpassa de outra forma a série. É a relação ser humano-doença, entendida aqui na representação da criatura alienígena. Principalmente no terceiro filme, o mais metafórico de todos, Ripley, o ser humano - que descobre que o pior está dentro de si mesmo -, pode muito bem representar esta ideia de vitimização do doente. No fundo, ela é vista como culpada pelo seu próprio mal. Junto com ela um terror pode se espalhar, da mesma maneira como muitos que contraíram a Aids nos anos 1980, e por que não no início da década seguinte, eram vistos e representados. O indivíduo é encarado como o grande desestruturador social, aquele que vai tirar a paz de todos, que vai aniquilar a "harmonia social", como diz o personagem Dillon em Alien 3. Uma harmonia que, na verdade, sequer existe ou existiu. Como os soropositivos nos anos 1980, atacados pelo discurso moralista de pregadores cristãos, de acordo com Susan Sontag, que tentam retomar em seus sermões uma vida que não se pautava em seus velhos padrões e que viam na epidemia de Aids a aproximação do fim do mundo.

Todos os filmes desta elogiada série de ficção científica têm seus méritos, porém, é no terceiro em que ficam mais claras as ideias sobre a doença e seu portador. Ripley se sacrifica. O peso cai sobre o indivíduo, que precisa se martirizar para purificar sua alma.

O martírio cristão, no entanto, não deve servir como exemplo? Cristo não morreu na cruz para nos livrar do pecado? Joana d'Arcnão dizia ouvir vozes divinas para guiar os exércitos contra o inimigo? Em nossa sociedade tão individualista, muitas vezes a questão da doença é totalmente centrada no indivíduo. Ele é o culpado por sua própria situação e é de dentro dele que deve vir esta espécie de "solução espiritual", se podemos usar essa expressão. E,nesse sentido, a linguagem cinematográfica não foge às formas de 
representação que muitas vezes tendem a simplificar totalmente as coisas.

Resumo: Este artigo discute como a representação de doença pode ser visualizada nos filmes da série de ficção científica Alien, uma das mais populares sagas cinematográficas de todos os tempos, e de que forma a ideia de enfermidade é ali apresentada. As fontes utilizadas nesta pesquisa são os quatro filmes da série norte-americana: Alien,ooitavo passageiro (Ridley Scott, 1979), Aliens, oresgate (James Cameron, 1986), Alien ${ }^{3}$ (David Fincher, 1992) e Alien:aressurreição (Jean-Pierre Jeunet, 1997). A questão central deste texto é analisar como, através da representação de um "alienígena", a ideia de doença se faz presente nos filmes em questão.

Palavras-chave: Cinema. Ficção científica.Doença.

Abstract: The problematic of this article is to discuss how the representation of illness can be visualized in movies of the series of Scientific Fiction Series Alien, one of the most popular cinematic saga of all times, and in what way the illness ideia is there presented. The sources used on this research are the four movies of this North American serie: Alien (Ridley Scott, 1979), Aliens (James Cameron, 1986), Alien 3 (David Fincher, 1992) and Alien: Ressurrection(JeanPierre Jeunet, 1997). The central question of this text is to analyze how, through of the representation of the "alien", the ideia of the illness is present in movies of this cinematic saga.

Keywords: Cinema; Scientific Fiction; Illness.

Artigo recebido para publicação em 18/05/2010

Artigo aprovado para publicação em 02/02/2011 